\title{
Induction of Agarwood Formation by Lignocellulolytic Bacteria
}

\author{
Prilya Dewi Fitriasari ${ }^{1 *}$, Endang Soetarto ${ }^{2}$, K Komang Surata ${ }^{3}$ \\ ${ }^{1}$ Biology Study Program, Sains and Technology Faculty, UIN Maulana Malik Ibrahim Malang \\ ${ }^{2}$ Biology Faculty, Universitas Gadjah Mada Yogyakarta \\ ${ }^{3}$ The Research Center for Non-Wood Forestry Products Technology Mataram \\ ${ }^{*}$ Corresponding author.Email: prilyadewi@bio.uin-malang.ac.id
}

\begin{abstract}
Agarwood is a hard-textured resin, has a scent of fragrant with blackish-brown color, and accumulated on the wood of the agarwood-producing tree. Gyrinops versteegii (Gilg.) Domke is one of the agarwood-producing trees, endemic in Lombok Island, West Nusa Tenggara. The resins were formed as a plant response to microbial infection. The research aimed to investigate the activity of bacterial isolates able to induce resin-formation. The bacteria were isolated from the stem of $G$. versteegii using mineral medium containing wood extracts as a carbon source. The selection of bacterial isolates was carried out based on their capability to grow on selective media containing different carbon sources (i.e. $\mathrm{CMC}$, xylan) to determine their enzyme properties. Bacterial isolates were able to grow with high activities and form a zone of degradation that was chosen as potential bacterial isolates to in planta assay. Five bacterial isolates (strain BPSA2a, BPSA2b, BPSB1, BPSB10, and BGG2) have potential as lignocellulolytic bacteria. In planta assay showed that after 30 days of injection, infection occurred with the decay of the surface of the bark, blackish-brown discoloration on the inside, and widen with varying color intensities, fragrant scent occurred after the wood was burned. Inoculated of potential bacterial isolates caused resins production with the number of extract yield of agarwood, respectively, were $6,78 \% ; 6,67 \% ; 5,30 \% ; 4,57 \%$, and 4,50\%. Dihydroagarofuran and $\beta$-agarofuran are the most compounds in these resins.
\end{abstract}

Keywords: Agarwood, Bacteria, Gyrinops versteegii, Resin

\section{INTRODUCTION}

Gyrinops versteegii (Gilg.) Domke was an endemic plant in Lombok Island, West Nusa Tenggara that producing agarwood. Agarwood (Aloeswood, Gaharu, Jinkoh, Oudh) is one of the non-timber forest products (NTFPs) commodity with high economic value with a nominal of 300.000 US dollars. In principle, agarwood can be used for medicine (as an analgesic, anti-diarrheal, anti-inflammatory agent, malaria, and cancer drug); incense as religious ceremonies and accessories; and fragrance [1].

Agarwood produced in nature has the quality and quantity that varied. Agarwood produced in forest varies from $0,3-14 \mathrm{~kg}$ per tree [2]. The production of agarwood is very limited as not all trees are capable to produce agarwood. The healthy agarwood-producing trees will never produce sesquiterpenoid as a fragrant secondary metabolite. Resin as secondary metabolites synthesized and accumulated by the plant as a response toward infection by microbial, physiology stimulation, or stress condition [3]. The resin then accumulated in included phloem, hardened, blackish-colored, and scent fragrant called as agarwood, identified as a sesquiterpenoid compound, defense compound of phytoalexin type [2].

Agarwood-forming is initiated by biotic or abiotic factors. To synthesize agarwood artificially can use mechanical wounding on the stem or chemical inducing method (i.e. methyl jasmonic, salicylic acid, gas ethylene, etc). Abiotic agarwood forming as mentioned above did not distribute its mechanism to other regions in the tree which was not directly affected by the abiotic factor. Fungi or other microbes are biotic-factor for inducing agarwood. Agarwood products would be more satisfying (both quality and quality) with biotic factors because the microbes let the agarwood-forming 
mechanism spread to other tissues on the tree [4]. Fusarium sp. mold is often used as a potential inducer to induce agarwood-forming [5]. Fusarium sp. isolates from West Nusa Tenggara were able to stimulate agarwoodforming on the branch Gyrinops versteegii after 1,5 years of induction [6]. However, the mechanisms of agarwood formation are still being researched. Induction artificially by using bacteria isolates has not been researched intensively, but bacteria can replicate their cell faster than mold. This research aims to obtain lignocellulolytic bacteria inducing resin agarwood-formation inside the stem of $G$. versteegii.

\section{MATERIALS AND METHODS}

\subsection{Collection of samples}

A treebark of $G$. versteegii was collected from the Pusuk region, West Lombok, and Genggelang region, North Lombok. G. versteegii tree was chosen randomly by selecting trees that showed wounds, brownish color in trunks, and never inoculated microbes artificially (the tree containing agarwood naturally). Tree trunks slashed use machete, samples stored in plastic and taken to the laboratory. The environment conditions are measured i.e. temperature, altitude, and humidity percentage.

\subsection{Isolation of Bacteria}

Samples were washed thoroughly with tap water and surface sterilized with sterile distilled water soaked for 30 seconds, followed by ethanol $70 \%$ for 60 seconds, washed three times with sterile distilled water, and blot dried on a sterile filter paper. The samples were destroyed using a blender to small pieces of sawdust. Samples (5 g) put in $45 \mathrm{~mL}$ Mineral Salt Medium (MSM) that has been enriched with extract wood. The culture incubated in an incubator shaker with constant agitation (150 rpm, 30 ${ }^{\circ} \mathrm{C}$ ) for 5-7 days [7]. After 7 days of incubation, cultures diluted with serial dilution method, each suspension $(0,1$ $\mathrm{mL}$ ) was then transferred to MSM-agar with spread plate technique, incubated for $24-48$ hours at $30{ }^{\circ} \mathrm{C}$. Individual colonies were purified by a single-cell colony technique streaked on nutrient agar medium.

\subsection{Screening of lignocellulolytic bacteria}

All the isolates were screened for their hemicellulolytic, cellulolytic, and ligninolytic abilities based on the qualitative test.

\subsubsection{Hemicellulolytic assay}

The hemicellulolytic ability of the cultures tested with the paper disk diffusion method (Wattman no.2, d-5 $\mathrm{mm})$ on mineral medium containing xylan $(0,2 \% \mathrm{w} / \mathrm{v})$ as the sole carbon source. The isolates producing hemicellulases showed clear zones around growth as zones of xylan hydrolysis after washed with iodine solution [8]. The hemicellulolytic index value is determined based on the ratio between the wide clear zones with an area of the colony [9].

\subsubsection{Cellulolytic assay}

The bacterial isolates were cultured on Carboxymethyl cellulose (CMC) liquid medium, incubated for 24 hours at $30{ }^{\circ} \mathrm{C}$ with constant agitation $(150 \mathrm{rpm})$. After 24 hours, the isolates transferred on CMC agar with the paper disk diffusion method (Wattman no.2, d-5 mm). After 5 days of incubation, the plates were flooded with Congo-red solution $(0,1 \% \mathrm{w} / \mathrm{v})$. The dye was drained off after 15 minutes and the plates were washed with $1 \mathrm{M}$ sodium chloride solution [10]. The isolates producing CMCase showed yellow zones around growth as zones of hydrolysis on CMC. The cellulolytic index value is determined based on the ratio between the wide clear zones with an area of the colony [9].

\subsubsection{Ligninolytic assay}

The ligninolytic ability of the cultures was tested by lignin peroxidase and laccase assays. For the detection of lignin peroxidase (LiP) enzyme, the bacterial isolates were grown on nutrient agar plates for 24 hours at $30^{\circ} \mathrm{C}$. Wells of $10 \mathrm{~mm}$ diameter were cut in the plates with the help of a disposable pipette. An aqueous solution $(25 \mu \mathrm{L})$ of pyrogallol $(1 \% \mathrm{w} / \mathrm{v}$, prepared by dissolving $1 \mathrm{~g}$ of pyrogallol in $100 \mathrm{~mL}$ of distilled water) and $25 \mu \mathrm{L}$ of freshly prepared hydrogen peroxide $(0,4 \% \mathrm{v} / \mathrm{v}$, prepared by mixing $0,4 \mathrm{~mL}$ of hydrogen peroxide in $100 \mathrm{~mL}$ of distilled water) were added to the wells. The plates were incubated for 10-24 hours in the darkroom at room temperature. The development of golden yellow to brown color around wells indicated the presence of lignin peroxidase activity. The wide of the zones was measured [11]. For the detection of laccase, the bacterial isolates were grown on tannic acid agar medium, incubated for 48 hours at $28^{\circ} \mathrm{C}$. The appearance of reddish-brown to blackish brown color around the bacterial colony indicated the presence of laccase [12][13].

\subsection{Inoculation of bacteria used in planta assay}

In planta-assay was referred to [14] research with modification. The twigs of $\mathrm{G}$. versteegii (about $10 \mathrm{~cm}$ length), excised from healthy G. versteegii, were washed thoroughly with tap water and surface sterilized with sodium hypochlorite $0,1 \%(\mathrm{w} / \mathrm{v})$ solution for 10 minutes. The twigs were washed five times with sterile distilled water and blot dried on a sterile filter paper. After dried, the twigs were then inoculated by completely dipping in bacterial suspension $\left(10^{8} \mathrm{CFU} / \mathrm{mL}\right)$ for $1-2$ hours after making a pinprick on the surface of the twigs and then spread on a sterile filter paper for drying excess moisture. The inoculated twigs of G. versteegii were kept in a 
plastic tray with moist blotting paper and incubated at $25^{\circ} \mathrm{C}$ for 30 days. Positive controls of twigs were soaked in Fusarium sp. strain GTO suspension (strains a collection of Research Center for Non-wood Forestry Technology). The physical changes such as wood color and scent were noted and compared with control. Resins compounds were detected using GCMS.

\subsection{Characterization of lignocellulolytic bacteria}

Characterization and identification of selected bacterial isolates were determined by observation of macroscopic character, microscopic morphology, biochemical and physiological test. Further identification of Genus was done by analyzing and comparing the results of characterization with Bergey's Manual of Determinative Bacteriology $9^{\text {th }}$ edition.

\section{RESULTS AND DISCUSSION}

\subsection{The samples collection}

The trees of G. versteegii used as a sample were at an altitude of 102-136 m/BSL, age 14-15 years, and wounded that indicated agarwood formation (Figure 1). The timber of G. versteegii was white but could be brownish discolored as an indicator formed agarwood besides as a result of the oxidizing process.

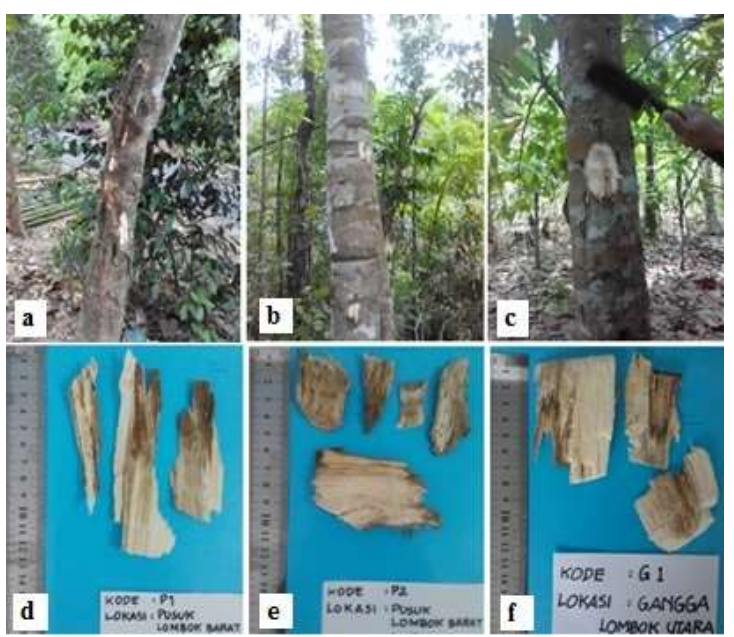

Figure 1. The materials as source of bacterial isolates from several locations.(a and b) G. versteegii tree in Pusuk - West Lombok; (c) G. versteegii tree in GanggaNorth Lombok; (d-f) a sliced of G. versteegii tree trunk.

The discoloration of wood in the agarwoodproducing tree from white into blackish brown was the early symptom of agarwood compound formation [15]. The discoloration can be caused by pathogen attack (fungus) and physical destruction. The pathogenic attack as Acremonium sp. and Fusarium sp. were associated with wood color change symptom and decline on Quercus sp. in New Zealand, while the wounding will result in loss of starch in the tissue cells formed blackish brown color [16]. The existence of wounds on $G$. versteegii makes the microbes easily infected and stimulated the formation of agarwood producing compounds.

\subsection{The bacterial isolates}

Thirty-eight strains of bacteria were isolated from three samples of $G$. versteegii wood. The bacteria colonies that were purified in basal medium containing wood extract suggest various macroscopic colonies). Most of the colonies have a milky white color of the colony, was able to change the color of the media to greenish nor others do not change the color of media, the form of the colony was circular, amoeboids, and irregular with low convex elevation.

\subsection{The bacteria screening assay results}

The isolates of bacteria were selected for the production of hemicelluloses, cellulose, and lignindegrading enzyme qualitatively, on media containing specific substrates (Figure 2). The isolates were adjudged for their hemicellulolytic abilities based on the zone clearance on xylan containing medium, which is indicative of hemicellulolytic capability (Figure 2b). Cellulolytic abilities of the isolates based on the zone of hydrolysis on CMC agar, which is indicative of endoglucanase activity, showed yellow zones around growth (Figure 2a). Lignin degrading capability of isolates was evident from the production of the brownish gold-colored zone on agar with pyrogallol and reddishbrown colored zone on tannic acid medium agar (Figure 2c and 2d).

Twelve bacterial isolates capable of degrades xylan with indicators the establishment of a clear zone around the colony of bacteria in medium xylan-agar after washed with iodine solution. The isolates, BGG11 produced the largest zones and highest index value of hemicellulolytic $(2,44)$, followed by the six isolates others that have an index value between 1-1,7 i.e. bacterial isolates strain BPSA2b, BPSA1, BPSB1, BPSB10, BPSB11, BPSA15. Five other bacterial isolates have a hemicellulolytic index value less than 1 i.e. BPSA2a, BPSB3, BGG2, BGG5, and BGG10. Xylan is the major constituent of the hemicelluloses present in plant biomass and hence utilization of xylan by an organism is indicative of its hemicellulolytic capability. Xylan is a polymer of pentose (xylose) with the amount of monomer ranged from 150-200 units [17][18]. Endo- $\beta$-1,4-xylanase and $\beta$-xylosidase were the enzymes that are involved in hemicelluloses break down. The enzymes that produced by hemicellulolytic bacteria will break down the bonds 
of $\beta$-1,4-glycosidic linkage that connects the main chain (homopolymer of D-xylopiranosa) on chains branch (i.e.O-acetyl, $\alpha$-L-arabinofuranosyl, D-glucoronyl, and o-methyl-D-glucoronyl) involved $\alpha$-Larabinofuranosidase, acetyl xylan esterase, $\alpha$ glucuronidase, and others types of enzymes [8].
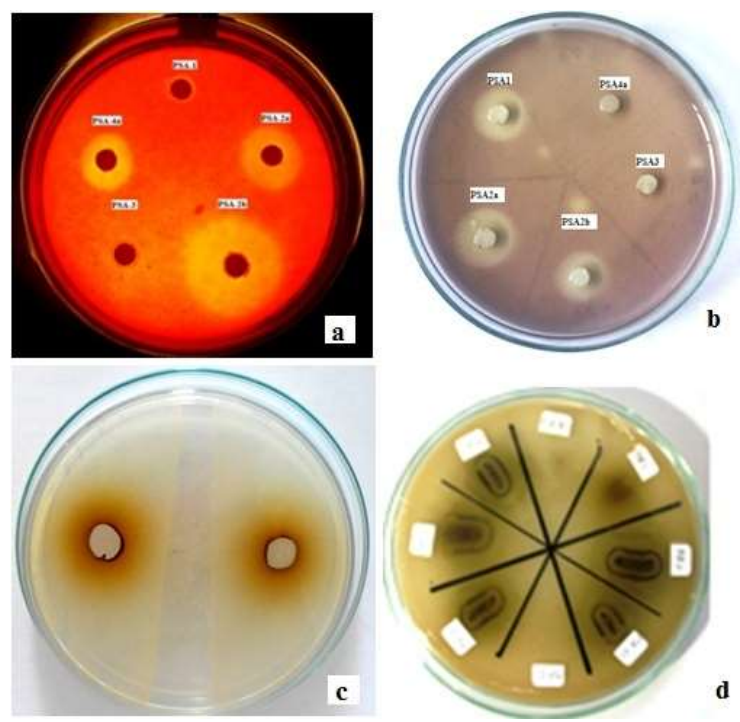

Figure 2. Screening of selected bacterial isolates on specific media. Cellulolytic (a), hemicellulolytic (b), and ligninolytic (c)(d).

The cellulolytic abilities indicated by 13 bacterial isolates of 38 isolates which showed yellow zones around the culture at the CMC-agar medium. The highest cellulolytic index values are 3,18 that showed by BPSA2a isolates, followed by bacterial isolates strain BGG7, BPSA2a, BPSA12 have an index value 2,93; 2,$81 ; 2,46$ respectively, while other isolates have index value less than 2 . The larger of cellulolytic zone indicate the higher cellulolytic activities [19]. CMC (Carboxy Methyl Cellulose) is a pure cellulose substrate that will be broken down into oligo-saccharide which is the result of endo-1,4- $\beta$-glucanase enzyme activity. This enzyme breaks down the bond of $\beta$-1,4-glycosidic in cellulose polymer [9]. The yellow zone as a result of the reaction between congo red as indicator reagent with $\beta-1,4-$ glycosidic linkage in cellulose polymer whiles the sodium chloride solution to reduce the color of the congo red (discolored) so that the hydrolysis zone formed more visible [20].

Lignin peroxidase (LiP), laccase (Lac) and manganese peroxidase $(\mathrm{MnP})$ were three main enzymes that play a role in the process of lignin depolymerization. However not all microorganisms have all the types of that enzymes at once, Bacillus sp. and Pseudomonas sp. were known as types of bacteria that capable of degraded lignin substrate. The result of the ligninolytic activity showed that 38 bacterial isolates have a lignin peroxidase (LiP) that indicated by the formation of brownish golden color around the wells after added with pyrogallol reagent. The laccase activity indicated by color development around cultures on tannic acid medium, 31 bacterial isolates capable to produce that enzyme (i.e. BGG1, BGG2, BGG3, BGG4, BGG5, BGG8, BGG9, BGG10, BGG11, BGG12, BPSA1, BPSA4a, BPSa5, BPSA7, BPSA14, BPSA15, BPSA16 and all isolates strain BPSB 1 until BPSB12 (data not shown). Lignin is a hydrophobic compound that is a polymer of conipheryl, sinaphyl, and p-coumaryl alcohol. The mechanism of lignin decomposition involved several enzymes that one of them is the main lignin peroxidase (LiP) that capable to oxidize non-phenolic units of lignin-formed aryl cation radical with the cutting $\mathrm{C}_{\alpha}-\mathrm{C}_{\beta}$ bond in lignin molecule and forming of intermediate compounds [21].

Based on the screening assay result, five isolates of bacteria have lignocelluloses enzyme (BPSA2a, BPSA2b, BPSB1, BPSB10, and BGG2). The potential lignocellulolytic bacteria also compared with the ability of lignocellulolytic fungus isolates (Fusariumsp. strain GTO) culture collection of Research Center for Nonwood Forestry Technology which have the capability to induced agarwood formation in G.versteegii (Figure 3). Bacterial isolates have a higher cellulolytic capability (index cellulolytic value an average of 2,02) than isolates Fusarium sp. strain GTO (index cellulolytic value 1,10). Based on the capabilities of hemicellulolytic activity, only PSA2b isolates that have a higher index value than isolates Fusarium sp. strain GTO. Based on the results of potential lignocellulolytic bacterial isolates was allegedly able to induce the agarwood resins formation in $G$. versteegii although more research needed to be done.

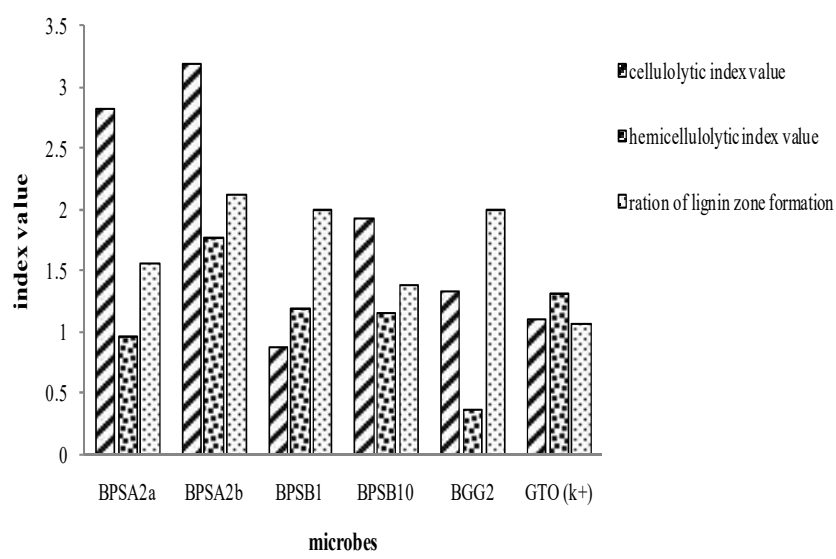

Figure 3. The potential lignocellulolytic activity of bacterial isolates and Fusarium sp.

\subsection{The physical and chemical changes after in-planta assay}

The results of the induction of five isolates of lignocellulolytic bacteria on a $G$. versteegii twigs for 1 month showed that the presence of decay on the twig surface, blackish-brown discoloration on the inside and widen with varying color intensities (Figure 4). The 
fragrant scent occurred after the wood was burned. The lowest color intensity was showed in wood without treatment (negative control), The intensity of the color was dark and almost spread in all area was induced by BPSA2b, BPSB1, BPSB10, and BGG2, while on positive control that inoculated with Fusarium sp. strain GTO showed the discoloration, the color changed into darker, occurred in the central of the wood. Discoloration of wood in the agarwood-producing tree from white into blackish brown was the early symptom of agarwood compound formation. These studies were only preliminary, and further research is required to identify the bacterial isolates' role during agarwood formation.

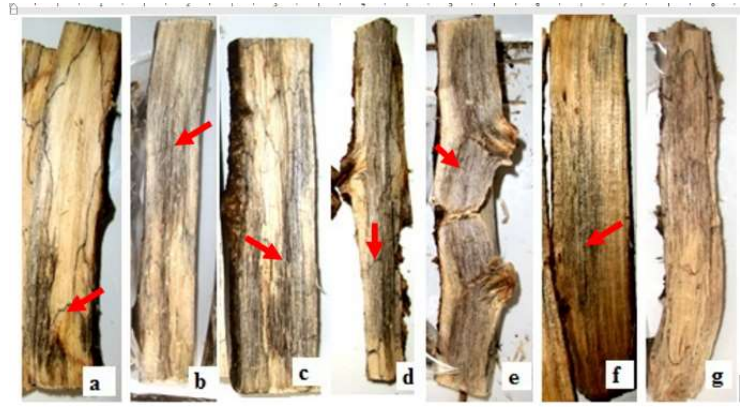

Figure 4. G. Versteegii wood color change after induced by bacterial inoculant induced by (a) BPSA2a, (b) BPSA2b, (c) BPSB1, (d) BPSB10, (e) BGG2, (f) Fusarium strain GTO (g) without inoculated as a negative control

The yield of resin showed that $G$. versteegii resin was blackish-brown and smelled good (Figure 5). The varying color intensity of resin (brown, dark brown) indicates that the darker the resin color is formed, the more fragrant the aroma will be. This fragrant aroma is caused by several compounds. Gas chromatographymass spectrometer analysis showed that Dihydroagarofuran and $\beta$ Agarofuran is the most compounds in these resins.

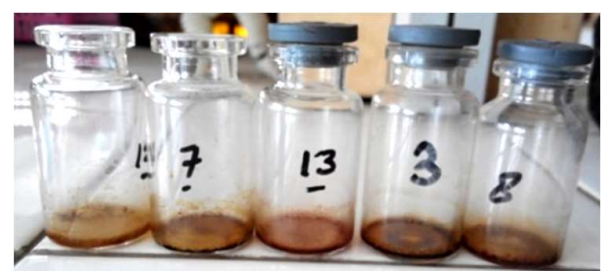

Figure 5. The resin of G. versteegii (Gilg.) Domke

Inoculated of potential bacterial isolates caused resins production with the number of extract yield of agarwood, respectively, were $6,78 \% ; 6,67 \% ; 5,30 \% ; 4,57 \%$, and $4,50 \%$. These results are close to the percentage of resin yield in Kemedangan III class or Kemedangan C class which has a resin yield value of $7.33 \%$ from aloes from South Sulawesi using the same extraction solvent, namely methanol.
The main compounds in agarwood are the derivative groups of sesquiterpene compounds ( $\alpha$-agarofuran, oxoagarospirol, 4-hydroxy-dihydro-agarofuran, baimuxinol, isobaimuxinol, nor-keto-agarofuran, agarospirol, jinkohol, jinkoh-eremol, jinkoholII) and phenylethyl chromone [22]. The chromone in the agarwood also causes the fragrant aroma of aloes when burned. Chromone and its derivatives also play a role in determining the quality of agarwood [23]. This showed that lignocellulolytic bacteria can induce agarwood resin formation on $G$. versteegii twigs through in planta experiments.

\subsection{The characteristic of bacteria}

Characteristics of the potential lignocellulolytic bacterial isolates showed in various. The result of identification showed that BPSA2a strain and BPSB1 strains were rod-shaped Gram-positive bacteria, BPSA2a was rod-shaped Gram-negative bacteria while BPSB10 and BGG2 were coccobasilGram-negative bacteria (Figure 6). Bacterial isolates strain BPSA2a and BPSB1 has a character similar to Bacillus sp., BPSB2b strains similar to Pseudomonas sp. and two other isolates (strains BPSB10 and BGG2) were actinomycetes, bacterial group.

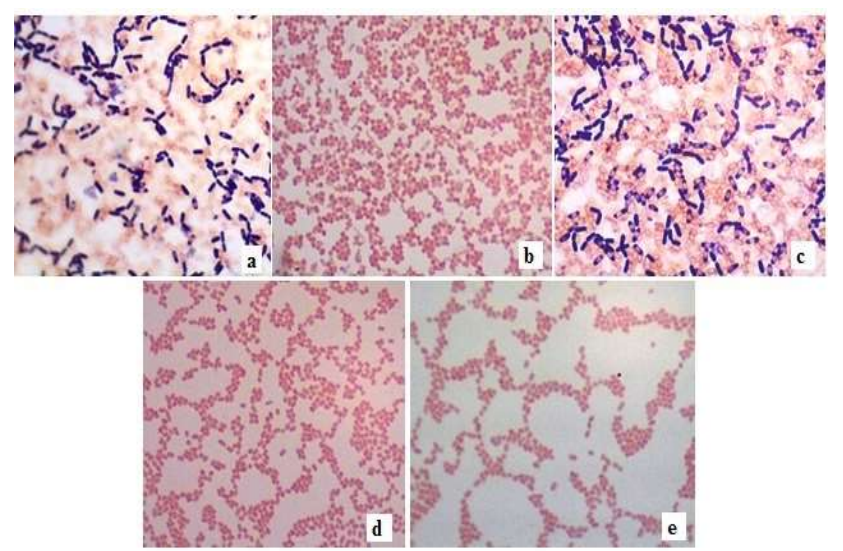

Figure 6. Photomicrograph of the bacterial cells. (a) BPSA2a strain, (b) BPSA2b strain, (c) BPSB1 strain, (d) BPSB10 strain and (e) BGG2 strain bacterial isolates.

Research about bacteria from agarwood producing tree $G$. versteegii has not been much done, one of the research was shown that bacterial endophyte in Aquilaria sp. (one of agarwood producing tree) was dominated by Bacillus, i.e. Bacillus pumillus [24], however, there is a possibility of other types of bacteria associated with agarwood producing trees from different species and locations. Research on the disease by a pathogenic microbe that attacks the trunk of $G$. versteegii has not much to do. Gonystylus sp. (one of the agarwoodproducing tree) was not found other pathogens that attack the tree except for the pathogens that caused the formation of agarwood from fungus i.e. Fusarium sp. and 
Acremonium sp. [25] so this research as the early research for bacteria from $G$. versteegii that have the lignocellulolytic ability, and the further research is required.

\section{CONCLUSION}

Five bacterial isolates from G.verstegii (Gilg.) Domke have potential as lignocellulolytic bacteria and initiating agarwood formation based in planta assay result contain Dihydroagarofuran and $\beta$-agarofuran resin accumulation.

\section{AUTHORS' CONTRIBUTIONS}

The first author is the main implementer of the project funded by the second author. The third author is a researcher at BPTHHBK who has researched agarwood

\section{ACKNOWLEDGMENTS}

The authors gratefully acknowledge Ir. Harry Budi Santoso, Yosephin M., Lutfi A., and all the staff at Research Center for Non-wood Forestry Technology (BPTHHBK) - West Lombok which has greatly provided the related facilities for this study.

\section{REFERENCES}

[1] A. Barden, A.A. Nooranie, M. Teresia, S. Michael, Heart of The Matter Agarwood Use and Trade and CITES Implementation on Aquilariamalaccensis, TRAFFIC Network, 2000.

[2] S. A. Siran, M. Turjaman, Pengembangan Teknologi Produksi Gaharu Berbasis Pemberdayaan Masyarakat, Pusat Penelitian dan Pengembangan Hutan dan Konservasi Alam, Bogor, 2010.

[3] Y. Isnaini, Induksi Produksi Gubal Gaharu melalui Inokulasi Cendawan dan Aplikasi Faktor Biotik, Disertasi. Program Pascasarjana. Institut Pertanian Bogor. Bogor. 2004.

[4] E. Santoso, S. Ragil, M. Turjaman, I.R. Sitepu, S. Santosa, Najmulah, A. Yani, Aryanto. Teknologi Induksi Pohon Penghasil Gaharu, Puslitbang Konservasi dan Rehabilitasi, Bogor, 2011.

[5] S. W. Budi, E. Santoso, A. Wahyudi, Identifikasi Jenis-Jenis Fungi yang Potensial terhadap Pembentukan Gaharu dari Batang Aquilaria spp., in: Jurnal Silvikultur Tropika. 1:1-5. ISSN: 2086-8227, 2010 .

[6] Nugraheni, Y.M.M.A \& L. Anggadhania. Inokulasi Sembilan Isolat asal Nusa Tenggara Barat untuk Pembentukan Gaharu pada Cabang Gyrinops versteegii. 2014. Prosiding Seminar Nasional Hasil Penelitian HHBK. Mataram. pp:190-197
[7] S. Yadav, N. Gangwar, P. Mittal, S. Sharma, T. Bhatnagar, Isolation, Screening and Biochemical Characterization of Laccase Producing Bacteria for Degradation of Lignin, IJESRR. 1: 17-21. E- ISSN 2348-6457, P- ISSN 2349-1817, 2014.

[8] L. Agustini, R.S.B. Irianto, M. Turjaman, E. Santoso, Isolates and Enzymatic Characterization of Lignocellulolytic Microbes Collected from Three Types of National Park Ecosystem, in: Jurnal Penelitian Hutan dan Konservasi Alam, 8: 200-201, 2011.

[9] A. Meryandini, W. Widosari, B. Maranatha, T.C. Sunarti, N. Rachmania, H. Satria, Isolasi Bakteri Selulolitik dan Karakterisasi Enzimnya. Makara Sains, 13:33-38, 2009.

[10] H.R. Gohel, , C. N. Contractor, S. K. Ghosh, V. J. Braganza, A Comparative Study of Various Staining Techniques for Determination of Extracellular Cellulase Activity on Carboxy Methyl Cellulose (CMC) Agar Plates, Int.J.Curr.Microbiol.App.Sci., 3: 261-266. ISSN: 2319-7706, 2014.

[11] M. Saritha, R. Tiwari, S. singh, S. Rana, A. adak, A. Sharma, A. Arora\& L. Nain. Bioprospecting for Superior Biomass Hydrolysing Fungi from Diverse Habitats, J. Biodivers Bipros Dev., 2:1-7, 2015.

[12] D. Brahmbhatt, H.A. Modi, Comparative Studies on Methods of Tannase Assay, IJRASET, 3: 715-717, 2015.

[13] M.I. Fonseca, P.D. Zapata, L.L. Villalba, J.I. Farina, Characterization of the Oxidative Enzyme Potential in Wild White Rot Fungi from Subtropical Forest of Misiones (Argentina). Acta. Biol. Colomb, 20: 47$56,2015$.

[14] K.N. Anith, N.V. Radhakrishnan, T.P. Manomohandas, Screening of Antagonistic Bacteria for Biological Control of Nursery Wilt of Black Pepper (Piper nigrum).Microbiol. Res. 158: 1-7, 2003.

[15] G. Rahayu, E. Santoso, E. Wulandari, Efektivitas dan Interaksi antara Acremonium sp. Dan Fusarium sp. dalam Pembentukan Gubal Gaharu pada Aquilaria microcarpa, Pusat Penelitian dan Pengembangan Hutan dan Konservasi Alam, Bogor, 2007.

[16] M. Braithwaite, C. Inglis, M.A. Dick, T.D. Ramsfield, N.W. Waipara, R.E. Beever, J.M. Pay, C.F. Hill, Investigation of Oak Tree Decline in Theauckland Region, New Zealand Plant Protection, 60: 297-303, 2007.

[17] B. C. Saha, Purification and Charachterization of an Extracellular a-xylosidase from Newly Isolated 
Fusariumverticilloides. J. Ind. Microbiol. Biotechnol, 30: 279-291, 2002.

[18] N. Richana, T.T. Irawadi, M.A. Nur, I. Sailah, K. Syamsu, Y. Arkenan, Ekstraksi Xilan dari Tongkol Jagung. J. Pascapanen. 4:38-43, 2007.

[19] K. Apun, B.C. Jong, M.A. Salleh, Screening and Isolation of Cellulolytic and AmylolyticBacillus from Sago Pith Waste. J. Gen. Appl. Microbiol, 46: 263-267, 2000 ,

DOI: https://doi.org/10.2323/jgam.46.263

[20] R. Nugraha, T. Ardyati, Suharjono, Ekplorasi Bakteri Selulolitik yang Berpotensi sebagai agen Biofertilizer dari Tanah Perkebunan Apel Kota Batu, Jawa Timur, in: Jurnal Biotropika, 2: 159-163, 2014.

[21] C. Urairuj, C. Khanongnuch, S. Lumyong, Ligninolyric Enzymes from Tropical Endophytic Xylariaceae, Fungal Diversity, 13:209-210, 2003.
[22] R. Naef, The Volatile and Semi-volatile Constituent of Agarwood, the Infected Heartwood of Aquilaria Species. A review. Flavour Frag. J, 26:73-89, 2011.

[23] T. Konishi, Takao, S. Yasuo, Shiu, Six New 2-(-2Phenethyl) chromone from Agarwood. Chem. Phem, Bull, 50(3):419-422, 2002.

[24] S.J. Bhore, J. Preveena, K.I. Kandasamy, Isolation and Identification of Bacterial Endophytes from Pharmaceutical Agarwood-producing Aquilaria Species, Pharmacognosy Research, 5(2): 134-137, 2013. DOI: https://doi.org/10.4103/09748490.110545

[25] K.S.S. Nair, Insect Pest and Disease in Indonesia Forest: an Assessment of the Major Threats, Research Efforts and Literature, Center for International Forestry Research, CIFOR, Bogor, 2000 . 